\title{
PENINGKATAN KUALITAS GURU DALAM PEMBELAJARAN MATEMATIKA SD MELALUI PENERAPAN REFLECTIVE TEACHING
}

\author{
Debrine Stefany \\ denysuper9@yahoo.com \\ Yeni Puji Astuti \\ yeni_puji.062003@yahoo.com \\ PGSD STKIP PGRI Sumenep
}

ABSTRACT

This study aims to encourage teachers to open up the flow of his thoughts and give an overview for teacher to constantly think very reflective of what has done, doing, and will do in the classroom. The research was conducted three times meeting in SDN Pangarangan I Sumenep, SDN Kolor II Sumenep , and SDN Pandian I Sumenep. The methods used in this study are qualitative and quantitative. The data was obtained as follows : (1) the process of development of teachers in designing lesson plans elementary mathematics is done through a phase of defining, designing, and development; (2) the quality of teachers in developing learning tools is increasing, the quality of teachers in managing learning activities is increasing, and the quality of teachers in materialize learning is increasing while the results of a student's response to learning that has done get good response then obstacles/barriers during the learning process only was found in trials meeting 1 for SDN Kolor II is located on teachers and SDN Pandian I is located on the teachers and students are not found obstacles/barriers during the learning process at SDN Pangarangan I; (3) the results of the application of reflective teaching is considered successful because of increased quality at every meeting held.The results of this research as a scientific contribution in the field of education on improving the quality of Primary teacher in teaching mathematics through the application of reflective teaching that both innovative and easy to apply in teaching.

Keywords: Teacher Quality, Reflective Teaching .

\begin{abstract}
ABSTRAK
Penelitian ini bertujuan mengajak guru untuk membuka alur pikirannya dan memberikan gambaran pada guru untuk secara terus-menerus memikirkan secara reflektif apa yang telah, sedang, dan akan dikerjakannya di dalam kelas.Penelitian ini dilaksanakan selama 3x pertemuan pada SDN Pangarangan I Sumenep, SDN Kolor II Sumenep, dan SDN Pandian I Sumenep. Metode/langkah penelitian yang digunakan adalah kualitatif dan kuantitatif.Data hasil penelitian yang diperoleh sebagai berikut: (1) proses pengembangan guru dalam mendesain perencanaan pembelajaran matematika SD dilakukan melalui tahap pendefinisian, perancangan, dan pengembangan; (2) kualitas guru dalam menyusun perangkat pembelajaran semakin meningkat, kualitas guru dalam mengelola kegiatan pembelajaran semakin meningkat, dan kualitas guru dalam keterlaksanaan pembelajaran semakin meningkat sedangkan hasil respons siswa terhadap pembelajaran yang telah dilakukan memberikan respon yang baik kemudiankendala/hambatan selama proses pembelajaran hanya ditemukan pada uji coba pertemuan 1 untuk SDN Kolor II terletak pada guru dan SDN Pandian I terletak pada guru maupun siswa namun tidak ditemukan kendala/hambatan selama proses pembelajaran pada SDN Pangarangan I; (3) hasil penerapan reflective teaching dinyatakan berhasil karena mengalami peningkatan kualitas pada setiap pertemuan yang dilakukan. Hasil penelitian ini sebagai sumbangan ilmiah dalam bidang pendidikan mengenai peningkatan kualitas guru dalam pembelajaran matematika SD melalui penerapan reflective teaching yang bersifat inovatif dan mudah diterapkan di SD lainnya untuk memperbaiki praktik-praktik pembelajaran guru sebagai perbaikan kualitas kinerja agar lebih meningkat.

Kata Kunci: Kualitas Guru, Reflective Teaching.
\end{abstract}




\section{A. PENDAHULUAN}

Pendidikan akhir-akhir ini mendapat sorotan tajam dari berbagai media, lingkungan ahli pendidik dan masyarakat umum lainnya sehingga diperlukan suatu pembaharuan dan alternatif-alternatif lain pada dunia pendidikan yang mampu mengubah pendidikan menjadi semakin bagus kualitasnya.Pembaharuan dilakukan pada semua aspek pendidikan baik dalam strategi pembelajaran, model pembelajaran, metode, dan media pembelajaran. Pembaharuan itu dilakukan untuk semua jenjang pendidikan dan berlaku untuk semua mata pelajaran seperti mata pelajaran Matematika. Pembaharuan dimulai dari sosok guru terlebih dahulu untuk meningkatkan kualitas di era global.

Pembaharuan pembelajaran yang dilakukan oleh guru didukung dengan adanya Undang-Undang No.14 tahun 2005 tentang Guru dan Dosen yang menyatakan bahwa guru sebagai pendidik profesional harus menguasai kompetensi pedagogik, kompetensi kepribadian, kompetensi sosial, dan kompetensi profesional. Kebijakan undang-undang tersebut memberikan dampak bagi semua guru, khususnya guru SD harus mampu mencapai standarisasi guru yang profesional tidak hanya dituntut untuk menguasai pengetahuan berdasarkan konten akademik yang diberikan pada siswa namun guru harus memiliki penguasaan keahlian secara utuh dalam melaksanakan pembelajaran di dalam kelas terutama pembelajaran matematika SD.

Dari hasil observasi melalui wawancara kepada guru dan siswa di tempat penelitian yang akan dilakukan diketahui bahwa guru maupun siswa memandang mata pelajaran matematika sebagai bidang studi yang sulit tetapi semua siswa harus mempelajarinya karena ilmu matematika merupakan salah satu bekal untuk memecahkan masalah kehidupan sehari-hari. Kesulitan matematika harus diatasi sedini mungkin agar tidak menimbulkan permasalahan di kemudian hari dan matematika adalah bidang studi yang harus dipelajari siswa dari SD sampai perguruan tinggi. Siswa dapat memahami matematika dengan baik apabila konsep dasar matematika yang diajarkan di SD dapat dikuasai dan dipahami oleh siswa. 
Untuk mencapai gambaran di atas secara optimal, kualitas guru harus dibangun dalam keahlian yang utuh meliputi pengetahuan, sikap, dan keterampilan untuk diimplementasikan secara kontinu dan konsisten sebagai guru yang berkualitas di bidangnya. Jika kompetensi dimaknai sebagai keahlian yang harus dimiliki setiap guru, maka kompetensi dalam mengajar di dalam kelas merupakan ujung tombak dalam proses pembelajaran agar siswa memiliki pengalaman belajar yang bermakna.

Kompetensi dalam mengajar meliputi: mengajar dan mengembangkan potensi siswa; merancang pembelajaran yang menarik; membangun pembelajaran yang menarik; danmemahami gaya mengajar guru adalah gaya belajar siswa (Suyanto dan Jihad, 2013:46-54). Sosok guru dengan segala keahliannya diharapkan mampu mendesain perencanaan pembelajaran, menjalin interaksi dan komunikasi dengan siswa, membangun motivasi belajar siswa, mengelola pembelajaran di dalam kelas maupun di luar kelas, serta mengevaluasi pembelajaran yang telah dilaksanakan sebagai bukti bahwa guru tersebut memberikan pengaruh pada kualitas pendidikan siswa.

Dari berbagai temuan di lapangan yang menunjukkan lemahnya kompetensi guru seperti hasil penelitian Musadad (2008) bahwa guru pemula kurang memiliki kemampuan dalam merancang pembelajaran, mengelola pembelajaran, dan membangun interaksi yang harmonis dengan siswa.Temuan Ansyar (2006) menyatakan bahwa umumnya guru pemula lulusan LPTK hanya berperan sebagai pembekal informasi dan pelaksana program instruksional sehingga memaknai pengajaran sebagai target bukan alat untuk mengembangkan potensi peserta didik, serta suasana pembelajaran di sekolah dan LPTK adalah kegagalan untuk menjadikan peserta didik memiliki kemampuan belajar sendiri (self directed learning).

Temuan lain milik Herpratiwi (2008) yang mengungkap tentang evaluasi kinerja praktikan dengan menggunakan penilaian acuan patokan ternyata masih rendah dan hal tersebut didukung dari 216 populasi mahasiswa PGSD Unila yang mendapatkan nilai B untuk aspek pengembangan strategi 
pembelajaran $37,04 \%$, penggunaan media 9,26\%, merumuskan tujuan pembelajaran $3,70 \%$, rencana evaluasi $0 \%$, kesesuaian materi $7,41 \%$, kesesuaian buku acuan 9,26\%, ketepatan waktu $5,55 \%$, penguasaan materi $3,70 \%$, kesesuaian materi dengan kehidupan nyata $3,70 \%$, dan selebihnya mendapatkan nilai di bawah kategori B sehingga tidak dapat dipungkiri bahwa kondisi tersebut dapat menjadi pemicu persoalan rendahnya kualitas proses pembelajaran ketika mereka sudah menjadi guru. Berdasarkan latar belakang di atas, sebuah penelitian untuk meningkatkan kualitas guru di era global sangat penting dilaksanakan agar guru SD mampu meningkatkan mutu pendidikan, khususnya dalam mendesain perencanaan dan melaksanakan proses pembelajaran di kelas sehingga penelitian ini berjudul "Peningkatan Kualitas Guru dalam Pembelajaran Matematika SD melalui Penerapan Reflective Teaching".

Secara umum tujuan penelitian ini adalah mengajak guru untuk membuka alur pikirannya dan memberikan gambaran pada guru untuk secara terus-menerus memikirkan secara reflektif apa yang telah, sedang, dan akan dikerjakannya di dalam kelas. Dengan menerapkan reflective teaching dapat memberikan kesadaran pada guru dan memberikan kesempatan secara sistematis untuk mengeksplorasi, mempertanyakan, dan membingkai kembali praktik pengajarannya secara holistik sehingga guru dapat membuat interpretasi secara benar berdasarkan keadaan di lapangan untuk menentukan pilihan yang tepat dalam memperbaiki kinerjanya.Tujuan umum ini dapat dijabarkan ke dalam tujuan-tujuan khusus sebagai berikut mendeskripsikan proses pengembangan guru dalam mendesain perencanaan pembelajaran matematika SD; (2) mendeskripsikan kualitas guru dalam pembelajaran matematika SD;dan (3) mendeskripsikan hasil penerapan reflective teaching pembelajaran matematika SD dalam meningkatkan kualitas guru SD.

Pelaksanaan dalam penelitian ini menggunakan tiga lokasi SD negeri yang ada di kota Sumenep dengan cara penentuan secara purposive sampling area, yaitu menentukan dengan sengaja daerah atau tempat penelitian berdasarkan beberapa pertimbangan 
tertentu, misalnya keterbatasan waktu, dana, tenaga (Arikunto, 2006:140).Pertimbangan lokasi penelitian yang ditentukan berdasarkan kesediaan SD tersebut sebagai tempat kegiatan penelitian dan SD tersebut belum pernah digunakan untuk penelitian sejenis sehingga tiga SD yang dipilih adalah sebagai berikut:SDN Pangarangan I Sumenep;SDN Kolor II Sumenep;SDN Pandian I Sumenep.

\section{B. METODE PENELITIAN}

Model yang digunakan dalam penelitian ini adalah model penelitian pengembangan 4-D untuk meningkatkan kualitas guru. Model pengembangan 4-D (Four D Models) yang dikembangkan oleh Thiagarajan meliputi empat tahap, yaitu define, design, develop, dan disseminate. Kemudian, model tersebut diadaptasi dalam bentuk model 4-P yang terdiri atas empat tahap yaitu pendefinisian, perancangan, pengembangan, dan penyebaran (Yulianto, 2009:37).

Penelitian ini menggunakan pendekatan kualitatif dan kuantitatif. Pendekatan kualitatif digunakan untuk mendeskripsikan proses pengembangan desain perencanaan pembelajaran, kualitas guru dalam melaksanakan pembelajaran, dan hasil penerapan reflective teaching sedangkan pendekatan kuantitatif digunakan untuk menyajikan data dalam bentuk angka berdasarkan hasil penilaian yang diamati meliputi data hasil validasi komponen perangkat pembelajaran, data aktivitas guru dalam melaksanakan pembelajaran, data keterlaksanaan pembelajaran yang telah dilakukan oleh guru, dan data hasil angket respons siswa terhadap kualitas guru dalam melaksanakan pembelajaran.

Dalam penelitian ini hal-hal yang diamati/diukur adalah sebagai berikut: (1) komponen perangkat pembelajaran yang dibuat oleh guru; (2) aktivitas guru dalam melaksanakan pembelajaran; (3) keterlaksanaan pembelajaran yang telah dilakukan oleh guru; (4) respons siswa terhadap kualitas guru dalam melaksanakan pembelajaran; hambatan-hambatan yang ditemui oleh guru saat proses pembelajaran berlangsung.

Teknik pengumpulan data yang digunakan dalam penelitian ini adalah sebagai berikut: (1) teknik catatan lapangan digunakan untuk mengetahui proses pengembangan guru dalam 
mendesain perencanaan pembelajaran matematika SD; (2) teknik validasi digunakan untuk menilai kualitas guru dalam pembelajaran matematika SD sehingga prosedur pengumpulan data dilakukan dengan cara memberikan penilaian terhadap komponen perangkat pembelajaran dan instrumen penilaian yang digunakan guru; (3) teknik observasi digunakan untuk mengumpulkan data tentang aktivitas guru dalam melaksanakan pembelajaran dan hambatan-hambatan yang ditemui oleh guru saat proses pembelajaran berlangsung sehingga prosedur pengumpulan data dilakukan dengan cara membuat catatan lapangan berdasarkan hasil pengamatan pada guru selama pelaksanaan pembelajaran dari awal hingga akhir; (4) teknik angket berbentuk ceklis skala penilaian digunakan untuk mengamati keterlaksanaan pembelajaran yang telah dilakukan oleh guru sehingga prosedur pengumpulan data dilakukan dengan cara membuat ratting scale dan checklist; (5) teknik angket tertutup digunakan untuk mengetahui respons siswa terhadap kualitas guru dalam melaksanakan pembelajaran sehingga prosedur pengumpulan data dilakukan dengan cara membagikan lembar angket di akhir pembelajaran.

Analisis data yang digunakan dalam penelitian ini adalah sebagai berikut: (1) analisis data deskriptif digunakan untuk menganalisis data tentang proses pengembangan guru dalam mendesain perencanaan pembelajaran matematika SD dan hambatan-hambatan apa saja yang ditemukan guru selama pelaksanaan pembelajaran sehingga prosedur penganalisisan data dilakukan dengan caramengecek hasil pengumpulan data yang diperoleh sesuai dengan catatan di lapanganmelakukan reduksi data sebagai bentuk analisis yang tajam, ringkas, terfokus, membuang data yang tidak penting, dan mengorganisasikan data;membuat display data dalam bentuk narasi;melakukan verifikasi dan menarik simpulan; (2) analisis data statistik deskriptif digunakan untuk menganalisis data tentang (a) kualitas guru dalam pembelajaran matematika SD dan aktivitas guru dalam melaksanakan pembelajaran sehingga prosedur penganalisisan data dilakukan dengan caramemberikan skor terhadap butir-butir kriteria yang perlu diberi skor;memberikan kode terhadap butir- 
butir kriteria yang tidak diberi skor;melakukan rekapitulasi data yang telah diperoleh;mengubah jenis data (disesuaikan dengan teknik analisis yang akan digunakan); mengolah data yang diperoleh dengan menggunakan rumus-rumus atau aturan-aturan yang sesuai dengan pendekatan penelitian yang telah ditentukan sehingga rumus penilaiannya:

Nilai Akhir $=\frac{\text { Jumlah skor yangdiperoleh }}{\text { Jumlah skor tertinggi }} \times 100 \%$

Hasil yang diketahui akan dicocokkan dan diinterpretasikan berdasarkan tabel berikut ini.

Tabel 1. Skala dan interpretasi penilaian kualitas gurudalam pembelajaran matematika SD

\begin{tabular}{clcl}
\hline Skala Nilai & \multicolumn{1}{c}{ Kriteria } & Persentase & \multicolumn{1}{c}{ Keterangan } \\
\hline 1 & $\begin{array}{l}\text { Kurang } \\
\text { baik }\end{array}$ & $0 \%-25 \%$ & $\begin{array}{l}\text { Belum dapat digunakan dan masih } \\
\text { memerlukan konsultasi lebih lanjut }\end{array}$ \\
\hline 2 & Cukup baik & $26 \%-50 \%$ & Dapat digunakan dengan banyak revisi \\
\hline 3 & Baik & $51 \%-75 \%$ & Dapat digunakan dengan sedikit revisi \\
\hline 4 & Sangat baik & $76 \%-100 \%$ & Dapat digunakan tanpa revisi \\
\hline
\end{tabular}

Tabel 2 Interpretasi penilaian hasil pengamatan aktivitas guru dalam melaksanakan pembelajaran

\begin{tabular}{cc}
\hline Kriteria & Persentase \\
\hline Kurang baik & $0 \%-25 \%$ \\
\hline Cukup baik & $26 \%-50 \%$ \\
\hline Baik & $51 \%-75 \%$ \\
\hline Sangat baik & $76 \%-100 \%$
\end{tabular}

(b) keterlaksanaan pembelajaran yang telah dilakukan oleh guru dan respons siswa terhadap kualitas guru dalam melaksanakan pembelajaran sehingga prosedur penganalisisan data dilakukan dengan caramemberikan skor terhadap butir-butir kriteria yang perlu diberi skor;memberikan kode terhadap butirbutir kriteria yang tidak diberi skor; melakukan rekapitulasi data yang telah diperoleh; mengubah jenis data (disesuaikan dengan teknik analisis yang akan digunakan); mengolah data yang diperoleh dengan menggunakan rumus-rumus atau aturan-aturan yang sesuai dengan pendekatan penelitian yang telah ditentukan dan mendeskripsikan hasil alternatif jawaban yang muncul berdasarkan uraian pertanyaan yang tercantum pada angket tersebut sehingga rumus penilaiannya:

Nilai Akhir $=\frac{\text { Jumlah skor yangdiperoleh }}{\text { Jumlah skor tertinggi }} \times 100 \%$

Hasil yang diketahui akan dicocokkan dan diinterpretasikan berdasarkan tabel berikut ini. 
Tabel 3 Interpretasi penilaian hasil pengamatan keterlaksanaan pembelajaran yang telah dilakukan oleh guru danrespons siswa terhadap kualitas guru dalammelaksanakan pembelajaran

\begin{tabular}{cc}
\hline Kriteria & Persentase \\
\hline Kurang baik & $0 \%-25 \%$ \\
\hline Cukup baik & $26 \%-50 \%$ \\
\hline Baik & $51 \%-75 \%$ \\
\hline Sangat baik & $76 \%-100 \%$
\end{tabular}

C. HASIL PENELITIAN DAN PEMBAHASAN

Proses Pengembangan Guru dalam Mendesain Perencanaan

\section{Pembelajaran Matematika SD}

Ada tiga tahap yang dilalui untuk meningkatkan kualitas guru dalam pembelajaran matematika SD, yaitu (1) tahap pendefinisian; (2) tahap perancangan; dan (3) tahap pengembangan. Tahapan tersebut merupakan bagian dari proses pengembangan guru dalam mendesain perencanaan pembelajaran matematika SD.

\section{(1) Tahap Pendefinisian}

Pada tahap ini, beberapa hal yang telah dilakukan dapat diuraikan sebagai berikut.

(a) Analisis Kurikulum KTSP

Pada tahap ini, kegiatan menganalisis Kurikulum KTSP telah guru lakukan di awal tahun pelajaran sesuai dengan ketentuan di masingmasing SD yang dijadikan tempat penelitian. Hasil yang diperoleh adalah mengetahui implementasi Kurikulum KTSP.

(b) Analisis Siswa

Pada tahap ini, kegiatan menganalisis siswa dilakukan masingmasing guru melalui hasil laporan di kelas sebelumnya dan dikaitkan dengan hasil laporan siswa pada saat semester ganjil maupun hasil perkembangan belajar siswa selama mengikuti semester genap. Hasil yang diperoleh adalah mengetahui siswa yang memiliki tingkat kemampuan beragam dengan cara memerhatikan ciri dan pengalaman belajar siswa, baik sebagai kelompok maupun individual. Jumlah siswa di kelas V SDN Pangarangan I Sumenep adalah 41 orang, jumlah siswa di kelas V SDN Kolor II Sumenep adalah 39 orang, dan jumlah siswa di kelas V SDN Pandian I Sumenep adalah 36 orang.

(c) Analisis Konsep dan Analisis Tugas

Pada tahap ini, kegiatan menganalisis konsep dan menganalisis tugas bagi siswa dilakukan guru 
Debrine Stefani, Yeni Puji Astuti: Peningkatan Kualitas Guru Dalam... |9

sebelum pelaksanaan pembelajaran sehingga menghasilkan beberapa sehingga akan menghasilkan rancangan indikator yang sesuai dengan RPP yang dapat mengatasi karakteristik siswa di masing-masing permasalahan yang dihadapi oleh siswa dan menghasilkan materi yang akan dipelajari oleh siswa secara sistematik, serta menemukan tahap-tahap penyelesaian tugas yang tepat agar kompetensi dasar yang telah ditentukan dapat tercapai. Berdasarkan analisis tersebut, siswa di kelas V SDN Pangarangan I Sumenep mempelajari KD $\quad 6.4$ Menyelidiki sifat-sifat kesebangunan dan simetri serta KD 6.5 Menyelesaikan masalah yang berkaitan dengan bangun datar dan bangun ruang sederhana.Untuk siswa di kelas V SDN Kolor II Sumenep mempelajari KD 6.1 Mengidentifikasi sifat-sifat bangun datar.Sedangkan, siswa di kelas V SDN Pandian I Sumenep mempelajari KD 6.1 Mengidentifikasi sifat-sifat bangun datar, KD 6.2 Mengidentifikasi sifatsifat bangun ruang, dan KD 6.3 Menentukan jaring-jaring berbagai bangun ruang sederhana.

(d) Perumusan Tujuan Pembelajaran Sesuai dengan Kurikulum KTSP Pada tahap ini, kegiatan merumuskan tujuan pembelajaran dilakukan pada saat merancang RPP sekolah.

(2) Tahap Perancangan

Pada tahap ini, beberapa hal yang telah dilakukan dapat diuraikan sebagai berikut.

(a) Penyusunan Perangkat Pembelajaran

Pada tahap ini, kegiatan mendesain perangkat pembelajaran telah dilakukan guru sesuai dengan program sekolah maupun program semester di masing-masing sekolah sehingga hasil yang diperoleh meliputi silabus, RPP, LKS, dan tes hasil belajar.

(b) Penyusunan Instrumen Penilaian yang akan Digunakan

Instrumen penilaian yang digunakan siswa di kelas V SDN Pangarangan I Sumenep adalah sebagai berikut.

1) Teknik penilaian menggunakan tugas kelompok.

2) Bentuk instrumen menggunakan uraian.

Instrumen penilaian yang digunakan siswa di kelas V SDN Kolor II Sumenep adalah sebagai berikut. 
10 | Premiere Educandum, Volume 6 Nomor 1, Juni 2016, 1 - 21

1) Teknik penilaian menggunakan tugas kelompok dan tugas individu.

2) Bentuk instrumen tugas kelompok menggunakan lembar pengamatan berdasarkan tampilan performansi dan hasil produk sedangkan bentuk instrumen tugas individu menggunakan pilihan ganda dan isian.

Instrumen penilaian yang digunakan siswa di kelas V SDN Pandian I Sumenep adalah sebagai berikut.

1) Teknik penilaian menggunakan tugas kelompok dan tugas individu.

2) Bentuk instrumen tugas kelompok menggunakan lembar pengamatan berdasarkan penilaian keterampilan (berkomunikasi, mendengarkan, dan partisipasi) dengan penilaian sikap (melakukan sesuatu tidak ragu-ragu, berani mengambil keputusan, tidak mudah putus asa, dan berani mencoba) sedangkan bentuk instrumen tugas individu menggunakan uraian.

(c) Validasi Komponen-Komponen Tahap Perancangan

Pada tahap ini, kegiatan validasi dilakukan oleh dua orang sebelum komponen tersebut digunakan untuk pelaksanaan pembelajaran.Hal yang dilakukan adalah memberikan masukan dan melakukan sharing terkait dengan penyusunan perangkat yang telah dibuat oleh masing-masing guru di SD yang telah ditentukan sebagai tempat penelitian.

(3) Tahap Pengembangan

Pada tahap ini, beberapa hal yang telah dilakukan dapat diuraikan sebagai berikut.

(a) Revisi Hasil Validasi

Pada tahap ini, kegiatan merevisi hasil validasi dilakukan oleh masingmasing guru untuk menindak lanjuti hasil masukan dari para validator sehingga layak untuk disimulasikan dan diuji cobakan.

(b) Uji Coba Pertemuan 1

Pada tahap ini, kegiatan uji coba pertemuan 1 dilakukan secara bergantian pada tiga SD yang telah ditentukan untuk jadwal pengambilan data penelitian. Uji coba pertemuan 1 di SDN Pangarangan I Sumenep dilakukan pada tanggal 4 Mei 2015 dengan jumlah siswa yang hadir 37 orang. Untuk uji coba pertemuan 1 di SDN Kolor II Sumenep dilakukan pada tanggal 8 Mei 2015 dengan jumlah siswa yang hadir 38 orang. Sedangkan, uji coba pertemuan 1 di SDN Pandian I 
Sumenep dilakukan pada tanggal 30 April 2015 dengan jumlah siswa yang hadir 34 orang. Kemudian hasil pelaksanaan pembelajaran yang telah dilakukan di masing-masing SD dapat dijadikan bahan refleksi pada akhir pembelajaran melalui hasil rekaman video yang dijadikan sebagai penerapan reflective teaching. Tim pengamat selama pelaksanaan pembelajaran berlangsung juga memberikan penilaian terhadap guru terkait dengan komponen perangkat pembelajaran yang dibuat oleh guru; aktivitas guru dalam melaksanakan pembelajaran; keterlaksanaan pembelajaran yang telah dilakukan oleh guru; respons siswa terhadap kualitas guru dalam melaksanakan pembelajaran; dan hambatan-hambatan yang ditemui oleh guru saat proses pembelajaran berlangsung. Hal ini dapat dijadikan pertimbangan guru sebagai bahan perbaikan dalam melakukan penerapan reflective teaching sebagai bahan perbandingan dari hasil penilaian tim pengamat dengan hasil rekaman video yang diperoleh.

(c) Uji Coba Lanjutan

Pada tahap ini, kegiatan uji coba lanjutan dilakukan sebanyak dua kali pertemuan di masing-masing SD yang telah ditentukan. Uji coba lanjutan pertemuan 2 di SDN Pangarangan I Sumenep dilakukan pada tanggal $6 \mathrm{Mei}$ 2015 dengan jumlah siswa yang hadir 41 orang dan pertemuan 3 dilakukan pada tanggal 11 Mei 2015 dengan jumlah siswa yang hadir 34 orang. Untuk uji coba lanjutan pertemuan $2 \mathrm{di}$ SDN Kolor II Sumenep dilakukan pada tanggal 13 Mei 2015 dengan jumlah siswa yang hadir 39 orang dan pertemuan 3 dilakukan pada tanggal 15 Mei 2015 dengan jumlah siswa yang hadir 36 orang. Sedangkan, uji coba lanjutan pertemuan 2 di SDN Pandian I Sumenep dilakukan pada tanggal $7 \mathrm{Mei}$ 2015 dengan jumlah siswa yang hadir 36 orang dan pertemuan 3 dilakukan pada tanggal 21 Mei 2015 dengan jumlah siswa yang hadir 34 orang. Hal yang sama juga dilakukan pada uji coba lanjutan pertemuan 2 dan 3 yaitu hasil pelaksanaan pembelajaran yang telah dilakukan di masing-masing SD dijadikan bahan refleksi pada akhir pembelajaran berdasarkan hasil rekaman video untuk mengetahui penerapan reflective teaching agar dijadikan pertimbangan guru untuk terus-menerus melakukan perbaikan 
pelaksanaan pembelajaran dan - Juli 2015.Hal yang harus dilakukan memperhatikan juga hal-hal yang telah adalah mengolah data sesuai dengan diamati oleh tim pengamat selama sumber data dan menginterpretasikan pelaksanaan pembelajaran berlangsung terkait dengan komponen perangkat pembelajaran yang dibuat oleh guru; aktivitas guru dalam melaksanakan pembelajaran; keterlaksanaan pembelajaran yang telah dilakukan oleh guru; respons siswa terhadap kualitas guru dalam melaksanakan pembelajaran; dan hambatan-hambatan yang ditemui oleh guru saat proses pembelajaran berlangsung. Dengan demikian, dapat dinyatakan bahwa kegiatan pada uji coba pertemuan 1 maupun uji coba lanjutan memiliki tahapan yang sama namun yang membedakan adalah hasil perbaikan yang semakin meningkat sebagai peningkatan kualitas guru dalam melaksanakan pembelajaran yang ideal terhadap siswa di kelas sesuai dengan materi yang akan dipelajari dan pencapaian indikator yang mendukung ketuntasan SK dan KD yang telah ditentukan.

(d) Analisis Data Hasil Penelitian

Pada tahap ini, kegiatan menganalisis data berdasarkan hasil penelitian dilakukan selama bulan Juni hasil yang diperoleh.

(e) Laporan

Pada tahap ini, kegiatan menyusun laporan penelitian dilakukan selama bulan Juli - Agustus 2015 sekaligus menghasilkan produk berupa $\mathrm{CD}$ penerapan reflective teaching yang bersifat obyektif maupun subyektif bagi masing-masing orang yang mengamati sebagai bahan refleksi dalam proses pembelajaran untuk memperbaiki kualitas guru dalam mengajar, khususnya pembelajaran matematika SD.

\section{Kualitas Guru dalam Pembelajaran} Matematika SD

Kualitas guru dalam pembelajaran matematika SD dapat ditentukan dari hasil pengamatan pada saat proses pembelajaran berlangsung melalui (1) lembar penilaian perangkat pembelajaran; (2) lembar pengamatan aktivitas guru; (3) lembar pengamatan keterlaksanaan pembelajaran; lembar angket respons siswa terhadap pembelajaran; dan (5) lembar pengamatan kendala/hambatan selama proses pembelajaran. Adapun hasil 
pengamatan yang telah dilakukan akan diuraikan sebagai berikut.
(1) Hasil Penilaian Perangkat Pembelajaran

Penilaian perangkat pembelajaran pada guru dilakukan oleh dua orang pengamat mulai dari uji coba pertemuan 1 hingga uji coba lanjutan pertemuan 2 dan 3 untuk masingmasing SD secara bergantian berdasarkan jadwal pengambilan data penelitian yang telah disepakati bersama. Hasil penilaian perangkat pembelajarandi SDN Pangarangan I Sumenep, dapat disimpulkan bahwa kualitas guru dalam menyusun perangkat pembelajaran mengalami peningkatan.Hal ini terbukti pada uji coba pertemuan 1, perangkat pembelajaran guru memperoleh jumlah skor rata-rata 68 berarti valid dan dinyatakan boleh digunakan setelah direvisi kecil.Untuk uji coba lanjutan pertemuan 2, perangkat pembelajaran guru memperoleh jumlah skor rata-rata 70 berarti valid dan dinyatakan boleh digunakan setelah direvisi kecil. Sedangkan uji coba lanjutan pertemuan 3 , perangkat pembelajaran guru memperoleh jumlah skor rata-rata 76,5 berarti valid dan dinyatakan boleh digunakan setelah direvisi kecil.

Hasil penilaian perangkat pembelajarandi SDN Kolor II Sumenep, dapat disimpulkan bahwa kualitas guru dalam menyusun perangkat pembelajaran mengalami kestabilan namun ada peningkatan. Hal ini terbukti pada uji coba pertemuan 1 dan uji coba lanjutan pertemuan 2 , perangkat pembelajaran guru samasama stabil memperoleh jumlah skor rata-rata 68,5 berarti valid dan dinyatakan boleh digunakan setelah direvisi kecil sedangkan uji coba lanjutan pertemuan 3, perangkat pembelajaran guru memperoleh jumlah skor rata-rata 70 berarti valid dan dinyatakan boleh digunakan setelah direvisi kecil.

Hasil penilaian perangkat pembelajaran di SDN Pandian I Sumenep, dapat disimpulkan bahwa kualitas guru dalam menyusun perangkat pembelajaran mengalami peningkatan.Hal ini terbukti pada uji coba pertemuan 1, perangkat pembelajaran guru memperoleh jumlah skor rata-rata 71 berarti valid dan dinyatakan boleh digunakan setelah direvisi kecil. Untuk uji coba lanjutan 
pertemuan 2, perangkat pembelajaran guru memperoleh jumlah skor rata-rata 73,5 berarti valid dan dinyatakan boleh digunakan setelah direvisi kecil. Sedangkan uji coba lanjutan pertemuan

3, perangkat pembelajaran guru memperoleh jumlah skor rata-rata 78 berarti valid dan dinyatakan boleh digunakan setelah direvisi kecil. Ketiga SD di bawah ini sama-sama mengalami peningkatan di masing-masing pertemuan sehingga kualitas guru dalam menyusun perangkat pembelajaran mengalami kemajuan/perbaikan sebagai hasil penerapan reflective teaching.

Tabel 4 Hasil rekapitulasi penilaian perangkat pembelajaran

\begin{tabular}{clccc}
\hline \multirow{2}{*}{ No. } & \multicolumn{1}{c}{ Nama SD } & \multicolumn{3}{c}{ Jumlah Skor Rata-Rata } \\
\cline { 3 - 5 } & & UC. P1 & UCL. P2 & UCL. P3 \\
\hline 1 & SDN Pangarangan I Sumenep & 68 & 70 & 76,5 \\
\hline 2 & SDN Kolor II Sumenep & 68,5 & 68,5 & 70 \\
\hline 3 & SDN Pandian I Sumenep & 71 & 73,5 & 78
\end{tabular}

(2) Hasil Pengamatan Aktivitas Guru Pengamatan aktivitas guru selama mengelola kegiatan pembelajaran dilakukan oleh dua orang pengamat mulai dari uji coba pertemuan 1 hingga uji coba lanjutan pertemuan 2 dan 3 untuk masingmasing SD secara bergantian berdasarkan jadwal pengambilan data penelitian yang telah disepakati bersama. Hasil pengamatan aktivitas gurudi SDN Pangarangan I Sumenep, dapat disimpulkan bahwa kualitas guru dalam mengembangkan kemampuan diri selama mengelola kegiatan pembelajaran sempat mengalami penurunan namun ada peningkatan.Hal ini terbukti pada uji coba pertemuan 1 , aktivitas guru memperoleh jumlah skor rata-rata 73 berarti baik dalam mengelola kegiatan pembelajaran. Untuk uji coba lanjutan pertemuan 2, aktivitas guru memperoleh jumlah skor rata-rata 72 berarti baik dalam mengelola kegiatan pembelajaran sedangkan uji coba lanjutan pertemuan 3, aktivitas guru memperoleh jumlah skor rata-rata 81,5 berarti sangat baik dalam mengelola kegiatan pembelajaran.

Hasil pengamatan aktivitas gurudi SDN Kolor II Sumenep, dapat disimpulkan bahwa kualitas guru dalam mengembangkan kemampuan diri 
Debrine Stefani, Yeni Puji Astuti: Peningkatan Kualitas Guru Dalam ... | 15

selama mengelola kegiatan pembelajaran mengalami peningkatan. Hal ini terbukti pada uji coba pertemuan 1, aktivitas guru memperoleh jumlah skor rata-rata 68 berarti baik dalam mengelola kegiatan pembelajaran. Untuk uji coba lanjutan pertemuan 2, aktivitas guru memperoleh jumlah skor rata-rata 71,5 berarti baik dalam mengelola kegiatan pembelajaran sedangkan uji coba lanjutan pertemuan 3, aktivitas guru memperoleh jumlah skor rata-rata 77,5 berarti baik dalam mengelola kegiatan pembelajaran.

Hasil pengamatan aktivitas gurudi SDN Pandian I Sumenep, dapat disimpulkan bahwa kualitas guru dalam mengembangkan kemampuan diri selama mengelola kegiatan pembelajaran mengalami peningkatan.
Hal ini terbukti pada uji coba pertemuan 1, aktivitas guru memperoleh jumlah skor rata-rata 70 berarti baik dalam mengelola kegiatan pembelajaran. Untuk uji coba lanjutan pertemuan 2, aktivitas guru memperoleh jumlah skor rata-rata 76 berarti baik dalam mengelola kegiatan pembelajaran sedangkan uji coba lanjutan pertemuan 3, aktivitas guru memperoleh jumlah skor rata-rata 83,5 berarti sangat baik dalam mengelola kegiatan pembelajaran. Ketiga SD di bawah ini sama-sama mengalami peningkatan di masing-masing pertemuan sehingga kualitas guru dalam mengembangkan kemampuan diri selama mengelola kegiatan pembelajaran mengalami kemajuan/perbaikan sebagai hasil penerapan reflective teaching.

Tabel 5 Hasil rekapitulasi pengamatan aktivitas guru

\begin{tabular}{clccc}
\hline \multirow{2}{*}{ No. } & \multicolumn{1}{c}{ Nama SD } & \multicolumn{3}{c}{ Jumlah Skor Rata-Rata } \\
\cline { 3 - 5 } & & UC. P1 & UCL. P2 & UCL. P3 \\
\hline 1 & SDN Pangarangan I Sumenep & 73 & 72 & 81,5 \\
\hline 2 & SDN Kolor II Sumenep & 68 & 71,5 & 77,5 \\
\hline 3 & SDN Pandian I Sumenep & 70 & 76 & 83,5 \\
\hline
\end{tabular}

(3) Hasil Pengamatan Keterlaksanaan Pembelajaran Pengamatan keterlaksanaan pembelajaran dilakukan oleh dua orang pengamat mulai dari uji coba pertemuan 1 hingga uji coba lanjutan pertemuan 2 dan 3 untuk masingmasing SD secara bergantian berdasarkan jadwal pengambilan data penelitian yang telah disepakati 
16 | Premiere Educandum, Volume 6 Nomor 1, Juni 2016, 1 - 21

bersama. Hasil pengamatan

mengalami peningkatan.Hal ini terbukti

keterlaksanaan pembelajarandi SDN pada uji coba pertemuan 1, Pangarangan I Sumenep, dapat keterlaksanaan pembelajaran yang disimpulkan bahwa kualitas guru dalam dilakukan guru memperoleh jumlah melaksanakan pembelajaran sesuai skor rata-rata 43 berarti cukup dengan skenario pembelajaran yang terlaksana skenario pembelajaran yang dirancang sempat mengalami dirancang. Untuk uji coba lanjutan penurunan namun ada peningkatan.Hal pertemuan 2, keterlaksanaan ini terbukti pada uji coba pertemuan 1 , keterlaksanaan pembelajaran yang dilakukan guru memperoleh jumlah skor rata-rata 50 berarti cukup terlaksana skenario pembelajaran yang dirancang. Untuk uji coba lanjutan pertemuan 2, keterlaksanaan pembelajaran yang dilakukan guru memperoleh jumlah skor rata-rata 48,5 berarti cukup terlaksana skenario pembelajaran yang dirancang sedangkan uji coba lanjutan pertemuan 3, keterlaksanaan pembelajaran yang dilakukan guru memperoleh jumlah skor rata-rata 54 berarti cukup terlaksana skenario pembelajaran yang dirancang.

Hasil pengamatan keterlaksanaan pembelajaran di SDN Kolor II Sumenep, dapat disimpulkan bahwa kualitas guru dalam melaksanakan pembelajaran sesuai dengan skenario pembelajaran yang dirancang pembelajaran yang dilakukan guru memperoleh jumlah skor rata-rata 46 berarti cukup terlaksana skenario pembelajaran yang dirancang sedangkan uji coba lanjutan pertemuan 3, keterlaksanaan pembelajaran yang dilakukan guru memperoleh jumlah skor rata-rata 50 berarti cukup terlaksana skenario pembelajaran yang dirancang.

Hasil pengamatan keterlaksanaan pembelajaran di SDN Pandian I Sumenep, dapat disimpulkan bahwa kualitas guru dalam melaksanakan pembelajaran sesuai dengan skenario pembelajaran yang dirancang sempat mengalami penurunan namun ada peningkatan.Hal ini terbukti pada uji coba pertemuan 1, keterlaksanaan pembelajaran yang dilakukan guru memperoleh jumlah skor rata-rata 52 berarti cukup terlaksana skenario pembelajaran yang dirancang. Untuk 
uji coba lanjutan pertemuan 2, pembelajaran yang dirancang. Ketiga keterlaksanaan pembelajaran yang SD di bawah ini sama-sama mengalami dilakukan guru memperoleh jumlah peningkatan di masing-masing skor rata-rata 51,5 berarti cukup pertemuan sehingga kualitas guru terlaksana skenario pembelajaran yang dalam melaksanakan pembelajaran dirancang sedangkan uji coba lanjutan sesuai dengan skenario pembelajaran pertemuan 3, keterlaksanaan yang dirancang mengalami pembelajaran yang dilakukan guru kemajuan/perbaikan sebagai hasil memperoleh jumlah skor rata-rata 52,5 penerapan reflective teaching. berarti cukup terlaksana skenario Tabel 6 Hasil rekapitulasi pengamatan keterlaksanaan pembelajaran

\begin{tabular}{clccc} 
No. & \multicolumn{1}{c}{ Nama SD } & \multicolumn{3}{c}{ Jumlah Skor Rata-Rata } \\
\cline { 3 - 5 } & & UC. P1 & UCL. P2 & UCL. P3 \\
\hline 1 & SDN Pangarangan I Sumenep & 50 & 48,5 & 54 \\
\hline 2 & SDN Kolor II Sumenep & 43 & 46 & 50 \\
\hline 3 & SDN Pandian I Sumenep & 52 & 51,5 & 52,5 \\
\hline
\end{tabular}

(4) Hasil Angket Respons Siswa terhadap Pembelajaran

Siswa diberikan angket setelah pembelajaran selesai untuk mengukur seberapa jauh pembelajaran yang telah terlaksana sesuai dengan pendapat masing-masing siswa dalam memahami materi yang diberikan oleh guru. Untuk SDN Pangarangan I Sumenep diperoleh hasil angket respons siswa bahwa ratarata respons siswa sejak pelaksanaan uji coba pertemuan 1 hingga uji coba lanjutan pertemuan 2 dan 3 dapat dinyatakan $90 \%$ siswa memberikan respons yang positif berdasarkan ratarata terbanyak jumlah respons siswa yaitu 37 dari 41 jumlah siswa di kelas tersebut. SDN Kolor II Sumenep diperoleh hasil angket respons siswa bahwa rata-rata respons siswa sejak pelaksanaan uji coba pertemuan 1 hingga uji coba lanjutan pertemuan 2 dan 3 dapat dinyatakan $97 \%$ siswa memberikan respons yang positif berdasarkan rata-rata terbanyak jumlah respons siswa yaitu 38 dari 39 jumlah siswa di kelas tersebut. SDN Pandian I Sumenep diperoleh hasil angket respons siswa bahwa rata-rata respons siswa sejak pelaksanaan uji coba pertemuan 1 hingga uji coba lanjutan pertemuan 2 dan 3 dapat dinyatakan 
18 | Premiere Educandum, Volume 6 Nomor 1, Juni 2016, 1 - 21

97\% siswa memberikan respons yang positif berdasarkan rata-rata terbanyak jumlah respons siswa yaitu 35 dari 36 jumlah siswa di kelas tersebut.

(5) Hasil

Pengamatan

Kendala/Hambatan Selama Proses

Pembelajaran

Berdasarkan hasil pengamatan yang dilakukan oleh dua orang pengamat, tidak ditemukan kendala/hambatan selama proses pembelajaran yang dialami oleh guru maupun siswa di SDN Pangarangan I Sumenep selama uji coba pertemuan 1 hingga uji coba lanjutan pertemuan 2 dan 3. Hal ini dikarenakan antara guru dan siswa sudah terbiasa menggunakan berbagai macam variasi pembelajaran, baik secara penggunaan model/metode/media pembelajaran sehingga interaktif antara guru dan siswa terjalin dengan baik.

Pada uji coba pertemuan 1 di SDN Kolor II Sumenep ditemukan kendala/hambatan selama proses pembelajaran yang dialami oleh guru berdasarkan hasil pengamat 1 yaitu guru terlalu fokus menulis sendiri dalam pembahasan soal latihan pada siswa sehingga kurang memberikan kesempatan bagi siswa untuk melatih kemampuan menulis hasil jawaban yang telah didiskusikan bersama anggota kelompok dan suara/volume guru kurang keras terdengar hingga posisi belakang tempat duduk siswa. Namun, pada uji coba lanjutan pertemuan 2 dan 3 tidak ditemukan kendala/hambatan selama proses pembelajaran yang dialami oleh guru maupun siswa. SDN Pandian I Sumenep pada uji coba pertemuan 1, ditemukan kendala/hambatan selama proses pembelajaran yang dialami oleh guru maupun siswa berdasarkan hasil pengamat 1 yaitu guru merasa kesulitan saat menggunakan media pembelajaran berbasis IT jika tidak dibantu/didampingi oleh operator sedangkan siswa merasa asing ketika pembelajaran terdapat dua orang pengamat yang melakukan proses perekaman pembelajaran menggunakan handycam sehingga banyak siswa yang kurang berani/kurang aktif saat pembelajaran berlangsung. Namun, pada uji coba lanjutan pertemuan 2 dan 3 tidak ditemukan kendala/hambatan selama proses pembelajaran yang dialami oleh guru maupun siswa. 
Hasil Penerapan Reflective Teaching Pembelajaran Matematika SD dalam Meningkatkan Kualitas Guru SD

Berdasarkan hasil rekaman video melalui handycam, dapat disimpulkan bahwa penerapan reflective teaching mampu meningkatkan kualitas guru dalam pembelajaran matematika SD. Cara ini dapat dianggap efektif untuk mengajak guru agar membuka alur pikirannya dan memberikan gambaran terhadap pembelajaran yang dilakukan sehingga guru dapat melakukan evaluasi diri secara reflektif apa yang telah, sedang, dan akan dikerjakannya di dalam kelas. Hasil penerapan reflective teaching menghasilkan produk berupa $\mathrm{CD}$ penerapan reflective teachingyang bersifat obyektif maupun subyektif bagi masing-masing orang yang mengamati sebagai bahan refleksi dalam proses pembelajaran untuk memperbaiki kualitas guru dalam mengajar, khususnya pembelajaran matematika SD. Hal ini dapat memberikan kesadaran pada guru dan memberikan kesempatan secara sistematis untuk mengeksplorasi, mempertanyakan, dan membingkai kembali praktik pengajarannya secara holistik sehingga guru dapat membuat interpretasi secara benar berdasarkan keadaan di lapangan untuk menentukan pilihan yang tepat dalam memperbaiki kinerjanya.

\section{SIMPULAN DAN SARAN}

\section{Simpulan}

Proses pengembangan guru dalam mendesain perencanaan pembelajaran matematika SD dapat dilakukan melalui tiga tahap, yaitu tahap pendefinisian, tahap perancangan, dan tahap pengembangan. Kualitas guru dalam menyusun perangkat pembelajaran, mengelola kegiatan pembelajaran, dan keterlaksanaan pembelajaran matematika SD mengalami kemajuan yang meningkat sedangkan hasil respons siswa terhadap pembelajaran memberikan respons yang positif. Kendala/hambatan selama proses pembelajaran hanya ditemukan pada uji coba pertemuan 1 untuk SDN Kolor II Sumenep terletak pada guru dan SDN Pandian I Sumenep terletak pada guru maupun siswa namun tidak ditemukan kendala/hambatan selama proses pembelajaran pada SDN Pangarangan I Sumenep. Hasil penerapan reflective teaching pembelajaran matematika SD dalam meningkatkan kualitas guru SD 
20 | Premiere Educandum, Volume 6 Nomor 1, Juni 2016, 1 - 21

mengalami peningkatan kualitas pada ketiga SD tersebut.

\section{Saran}

Hasil penelitian yang diperoleh di SDN Pangarangan I Sumenep, SDN Kolor II Sumenep, dan SDN Pandian I Sumenep diharapkan dapat melengkapi kajian mengenai pengembangan peningkatan kualitas guru dalam pembelajaran matematika SD melalui penerapan reflective teaching yang bersifat inovatif dan mudah diterapkan di SD lainnya untuk memperbaiki praktik-praktik pembelajaran guru sebagai perbaikan kualitas kinerja. Bagi siswa kelas V, khususnya dalam pembelajaran matematika SD akan termotivasi dan lebih aktif saat pembelajaran tergantung dari kualitas guru dalam melaksanakan pembelajaran yang efektif dan efisien di dalam kelas. Namun, bagi peneliti lain yang tertarik pada penelitian ini dapat dijadikan sumber referensi untuk diadakan penelitian lanjutan dengan kelas yang berbeda atau pada materi yang lain.

\section{DAFTAR PUSTAKA}

Abdurrahman, Mulyono. 2003. Pendidikan Bagi Anak Berkesulitan Belajar. Jakarta: PT Rineka Cipta.
Ansyar. 2006. Pemantapan Fungsi LPTK dalam Pendidikan Prajabatan Tenaga Kependidikan. Forum Pendidikan Universitas Negeri Padang.

Bartlett, Leo. 1990. "Teacher Development through Reflective Teaching" dalam Richards, Jack C. dan Nunan, David (eds.). Second Language Teacher Education, $202-214$. Cambridge: Cambridge University Press.

Depdiknas. 2008. Kurikulum Tingkat Satuan Pendidikan. Jakarta: Dikmenum Depdiknas.

Henke, Niura Regiane. 2001. Reflective Teaching. Disal, New Route: http://www.disal.com.br/nroutes/ nr5/pgnr5_08.htm

Herpratiwi.2008. Studi Evaluasi Kinerja PPL Mahasiswa PGSD. Bandar Lampung: Jurnal Penelitian Pendidikan dan Pembelajaran. Unila.

Heruman. 2014.Model Pembelajaran Matematika di Sekolah Dasar. Bandung: PT Remaja Rosdakarya.

Joni, Raka T. 1992. Pokok-Pokok Pikiran Mengenai Pendidikan Guru. Jakarta: Konsorsium Ilmu Pendidikan, Direktorat Jenderal Pendidikan Tinggi, Departemen Pendidikan dan Kebudayaan.

Karso, dkk. 2008. Pendidikan Matematika I. Jakarta: Universitas Terbuka. 
Loughran, J. John. 1996. Developing Reflective Practice: Learning about Teaching and Learning through Modelling. London: Falmer Press.

Musadad, Akhmad Arif. 2008. Kemampuan Guru Pemula; hasil penelitian. Surabaya: Jurnal Penelitian Paedagogi Jilid 11, Nomor 1, Februari 2008, halaman 51-61 Unes.

Sanjaya, Wina. 2006.Strategi Pembelajaran Berorientasi Standar Proses Pendidikan. Jakarta: Kencana Prenada Media Group.

Suherman, Erman., Turmudi., Didi Suryadi., Tathung Herman., Suhendra., Sufyani Prabawanto., Nurjanah., Ade Rohayati. 2003. Common Text Book (Edisi Revisi) Strategi Pembelajaran Matematika Kontemporer. Bandung: JICA.

Suherman, W. 2010.Pengajaran Reflektif. Yogyakarta: Universitas Negeri Yogyakarta.

Suyanto dan Jihad. 2013. Menjadi Guru Profesional: Strategi Meningkatkan Kualifikasi dan Kualitas Guru di Era Global. Jakarta: Erlangga.

Taufiq, Agus dkk. 2010.Pendidikan Anak di SD. Jakarta: Universitas Terbuka. 